\title{
ОЦЕНКА ЧАСТОТЫ ТРЕВОЖНОСТИ У ДЕТЕЙ ШКОЛЬНОГО ВОЗРАСТА С САХАРНЫМ ДИАБЕТОМ 1 ТИПА В ЗАВИСИМОСТИ ОТ КОМПЕНСАЦИИ УГЛЕВОДНОГО ОБМЕНА
}

\section{Навменова Я.Л., Махлина Е.С.}

Республиканский научно-практический центр радиационной медицины и экологии человека, Республика Беларусь, г.Гомель

Цель исследовать частоту тревожности у детей школьного возраста с сахарным диабетом 1 типа (СД 1) в зависимости от компенсации углеводного обмена.

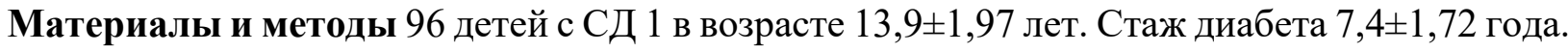
Определялся уровень гликированного гемоглобина $\left(\mathrm{HbA}_{1)}\right.$. Уровень $\mathrm{HbA}_{1}$ 7,5\% и более свидетельствовал о декомпенсации углеводного обмена. Оценка степени тревожности проводилась с применением шкалы самооценки уровня тревожности Спилбергера-Ханина с определением реактивной (РТ) и личностной тревожности (ЛТ). Пациенты были разделены на 2 подгруппы: 1-я с уровнем $\mathrm{HbA}_{1} 7,5 \%$ и выше $(\mathrm{n}=35)$ и 2-я с уровнем $\mathrm{HbA}_{1}$ до $7,5 \%(\mathrm{n}=61)$.

Результаты В 1 - ой группе высокая ЛТ выявлена у 10 человек $(28,6 \%)$; высокая РТ у 13 человек $(37,14 \%)$. Во 2-ой группе высокая ЛТ выявлена у 11 человек $(18,0 \%)$, а высокая РТ у 9 человек (14,7\%). Частота высокой ЛТ в 1-ой группе была достоверно выше, чем во 2-ой группе $\left(\chi^{2}=5,75, \mathrm{p}=0,01\right)$. Частота РТ в 1-ой группе была также выше, чем во 2-ой группе $\left(\chi^{2}=8,81, \mathrm{p}=0,03\right)$. Риск развития высокой ЛТ значимо увеличивал рост уровня $\mathrm{HbA}_{1}(\mathrm{~b}=0,16)$ $(\operatorname{Exp}(b)=1,18 ; 95 \%$ ДИ $-1,03 \div 1,34 ; p<0,02)$.

Заключение Частота встречаемости высокой тревожности как личностной, так и реактивной достоверно выше у пациентов с декомпенсацией углеводного обмена.

Риск развития высокой личностной тревожности увеличивается при прогрессировании декомпенсации углеводного обмена. 